\title{
Methodological proposal for the assessment of environmental aspects in Higher Education Institutions (HEls)
}

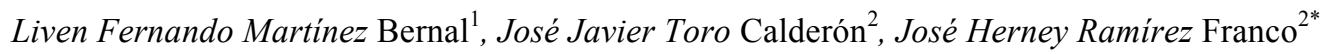 \\ ${ }^{1}$ Institute of Environmental Studies - Universidad Nacional de Colombia - Bogotá Seat. \\ ${ }^{2}$ Department of Chemical and Environmental Engineering - Universidad Nacional de Colombia - Bogotá Seat*
}

\begin{abstract}
This work proposes a methodology specially aimed at Higher Education Institutions (HEIs). The methodology is based on the use of quantitative and qualitative indicators that allow diminishing the assessment's subjectivity and the uncertainty of the results. This proposal was designed within the implementation of Environmental Management Systems (EMS) according to the ISO standard $14.001 / 2015$, so it can be applied by any kind of organization interested in improving its environmental performance by identifying its environmental aspects, as well as assessing and preventing its environmental impacts. The methodological proposal assesses standard criteria like the affected area and the frequency of the activities that generate the environmental aspects. This analysis is complemented by innovative indicators such as the danger of the substances related to the environmental aspect, the time of exposure and the effects on human health. Additionally, some indicators that allow measuring the magnitude of the harm generated by the identified aspects are also included. The proposed approach has two main advantages: first, it allows integrating the environmental analysis with other management systems, such as the Occupational Health and Safety Assessment Series (OHSAS 18001), quality (ISO 9001) and general requirements for the competence of testing and calibration laboratories (ISO 17025), among others; and second, it establishes an indicators system whose frequent assessment allows following up the environmental aspects and evaluate the effectiveness of its management measures. The application of this methodology in the main seat of Universidad Nacional de Colombia revealed that the most significant environmental aspects were: generation of ordinary solid waste, consumption of potable water, consumption of electric power, generation of recyclable solid waste, and wastewater discharge.
\end{abstract}

\section{Introduction}

The HEIs work as a system where exchanges of matter, energy and information take place, even though their missional purpose is the training and generation of knowledge, rather than the production of goods and services for the market or the business sector.

In the development of their missional functions, the HEIs generate environmental impacts that affect the university communities (students, teachers and administrative staff) and interfere with the learning and teaching processes, as well as with the human health and the natural resources of the campuses.

As a consequence, a high number of HEIs worldwide have turned to the implementation of EMS from a preventive approach as a strategic measure that integrates the university community in general and constitutes a didactic tool for environmental education.

The main basis of the EMS is the determination of those activities or actions developed by the HEIs that may interact with the environment. They are called Environmental Aspects (EA) and their identification and scope is essential for the subsequent design of action plans. The methodologies for their identification and assessment are mostly qualitative, therefore their associated subjectivity and uncertainty may interfere with the objectives of the EMS.

A methodology for the assessment of the EA has been designed taking into account this necessity. This proposal is based on the analysis of objective indicators that provide more credibility and it is framed in the implementation of EMS according to the ISO standard $14.001 / 2015$, so it can be applied by any kind of organization interested in improving its environmental performance by identifying its environmental aspects, as well as assessing and preventing its environmental impacts. The proposed methodology was tested in Universidad Nacional de Colombia (Bogotá Seat) and it allowed obtaining more objective results and criteria that will contribute to a more effective decision-making process in the short, medium and long term. Table 1. Setting Word's margins. Use a two-column format, and set the spacing between the columns at $8 \mathrm{~mm}$. Do not add any page numbers.

\section{Conceptual foundations}

According to the ISO 14001 standard, an EA is an element of the organization's activities, products or services that may interact with the environment. Carretero (2007) points out that "an EA is something

\footnotetext{
*Corresponding author: jhramirezfra@,unal.edu.co
} 
generated by an activity [1], product or service that may have incidence on the environment, which is defined as the natural setting that contains those EA as well as other living beings". Two concepts are proposed for the development of this methodology: unit of analysis (UA) and macro unit (MU). The UA refers to a space or a combination of spaces presenting homogeneous physical conditions and where common activities take place, so they have similar EA. Spaces such as warehouses, auditoriums, libraries, cafeterias, sport halls, laboratories, offices, classrooms and green areas can be considered as UA. On the other hand, the MU is the combination of UA that belong to a physical space clearly distinguishable due to its structural elements (e.g., a building). Unlike the UA, several types of activities may take place inside an MU.

\section{Methodological proposal}

This methodology has two main stages: identification of EA and their assessment. The following are the steps for its application.

\subsection{Staff selection and training}

Once the processes developed by the institution have been identified, a group of interviewers must be selected and trained. One MU will be assigned to each interviewer, who must identify all the UA and the person in charge in order to schedule an interview. Thus, will be obtained the information required to assess the EA.

\subsection{Identification of UA and associated activities}

The interviewee must provide all the information related to the activities developed in his/her UA. These activities must be grouped into generic categories, according to their nature. For instance, if the interviewee performs duties such as answering emails and writing documents, these tasks can be grouped into the "office and IT activities".

\subsection{Identification of EA}

Once the generic activities of each UA are defined, then the EA must be identified. In the case of Universidad Nacional de Colombia (Bogotá Seat), 33 EA were determined (see Table 1).

\subsection{Assessment of EA}

The assessment of the EA's significance takes into account the attributes of time, severity and magnitude:

Table 1. EA identified at Universidad Nacional de Colombia Bogotá Seat. Source: based on [1] and [2]

\begin{tabular}{|c|c|c|c|}
\hline \multicolumn{3}{|c|}{ EA } \\
\hline 1 & Combustion emissions & 19 & $\begin{array}{c}\text { Generation of fat, oil and } \\
\text { grease waste }\end{array}$ \\
\hline
\end{tabular}

\begin{tabular}{|c|c|c|c|}
\hline \multicolumn{4}{|c|}{ EA } \\
\hline 2 & Non-combustion emissions & 20 & Disposal of tires \\
\hline 3 & Noise emissions & 21 & $\begin{array}{c}\text { Disposal of rechargeable } \\
\text { batteries }\end{array}$ \\
\hline 4 & Emissions of offensive odors & 22 & $\begin{array}{c}\text { Disposal of alkaline } \\
\text { batteries }\end{array}$ \\
\hline 5 & Saturation of visual objects & 23 & Disposal of light bulbs \\
\hline 6 & $\begin{array}{l}\text { Discharge of domestic } \\
\text { wastewater }\end{array}$ & 24 & $\begin{array}{l}\text { Disposal of waste of } \\
\text { electrical and electronic } \\
\text { equipment (WEEE) }\end{array}$ \\
\hline 7 & $\begin{array}{l}\text { Discharge of water with } \\
\text { environmental effects }\end{array}$ & 25 & $\begin{array}{c}\text { Disposal of tonners and } \\
\text { cartridges }\end{array}$ \\
\hline 8 & $\begin{array}{l}\text { Discharge of water with } \\
\text { sanitary effects }\end{array}$ & 26 & $\begin{array}{l}\text { Disposal of expired } \\
\text { medications }\end{array}$ \\
\hline 9 & Generation of leachates & 27 & $\begin{array}{l}\text { Disposal of pesticide } \\
\text { containers }\end{array}$ \\
\hline 10 & $\begin{array}{c}\text { Generation of biodegradable } \\
\text { waste }\end{array}$ & 28 & $\begin{array}{c}\text { Consumption of potable } \\
\text { water }\end{array}$ \\
\hline 11 & $\begin{array}{c}\text { Generation of ordinary solid } \\
\text { waste }\end{array}$ & 29 & $\begin{array}{l}\text { Consumption of non- } \\
\text { potable water }\end{array}$ \\
\hline 12 & Generation of inert waste & 30 & $\begin{array}{c}\text { Consumption of electric } \\
\text { power }\end{array}$ \\
\hline 13 & $\begin{array}{c}\text { Generation of recyclable solid } \\
\text { waste }\end{array}$ & 31 & $\begin{array}{l}\text { Consumption of fossil } \\
\text { fuels }\end{array}$ \\
\hline 14 & $\begin{array}{l}\text { Generation of bio-sanitary } \\
\text { waste }\end{array}$ & 32 & Consumption of paper \\
\hline 15 & Generation of sharps waste & 33 & $\begin{array}{c}\text { Consumption of } \\
\text { disposable materials }\end{array}$ \\
\hline 16 & $\begin{array}{l}\text { Generation of human } \\
\text { anatomopathological waste }\end{array}$ & 34 & $\begin{array}{l}\text { Consumption of } \\
\text { fertilizers }\end{array}$ \\
\hline 17 & $\begin{array}{c}\text { Generation of animal } \\
\text { anatomopathological waste }\end{array}$ & 35 & $\begin{array}{c}\text { Consumption of } \\
\text { pesticides }\end{array}$ \\
\hline 18 & Generation of chemical waste & & \\
\hline
\end{tabular}

Time: it is assessed according to the frequency of the EA and its duration (in hours). The ranks presented in Table 2 must be used in order to assess this attribute. The logarithm base 5 of the total of hours of EA per year (obtained from the multiplication of the frequency and the duration) was calculated to define the values included in Table 2. Values below 1 were approximated to that number, so that the scale could be limited to the rank from 1 to 5 , and thus the significance of the EA is not underestimated (those values are identified in Table 2 with an asterisk).

- Severity: it is calculated from the interaction between the coverage (range), danger and effects of the EA on human health. Table 3 includes the description of each component of this attribute.

- Magnitude: it refers to the quantification of the EA based on quantitative or qualitative indicators. In order to assess this criterion, the results obtained from the indicators must be classified into 5 categories, each one of them with a particular value: "very high" (10), "high" (8), "medium" (6), "low" (4) and "very low" (2). The use of these categories and their associated values allows to standardize the magnitude of the EA, regardless of the units that were employed for their measurement. Some of the proposed indicators for the assessment of the EA in the case of Universidad 
Nacional de Colombia (Bogotá Seat) are presented in Table 4. The defined values and ranges for these indicators are included in Table 5.

Table 2. Scale of values for the assessment of the Time attribute (own elaboration).

\begin{tabular}{|c|c|c|c|c|c|c|c|c|c|c|c|c|c|c|}
\hline \multirow{2}{*}{\multicolumn{2}{|c|}{ Frequency }} & \multicolumn{13}{|c|}{ Duration (hours) } \\
\hline & & $\leq 1$ & 2 & 3 & 4 & 5 & 6 & 7 & 8 & 9 & 10 & 11 & 12 & $\geq 13$ \\
\hline Daily & 240 & 3.4 & 3.8 & 4.1 & 4.3 & 4.4 & 4.5 & 4.6 & 4.7 & 4.7 & 4.8 & 4.9 & 5 & 5 \\
\hline Weekly & 54 & 2.5 & 2.9 & 3.2 & 3.3 & 3.5 & 3.6 & 3.7 & 3.8 & 3.8 & 3.9 & 4 & 4 & 4.1 \\
\hline Biweekly & 27 & 2.1 & 2.5 & 2.7 & 2.9 & 3.1 & 3.2 & 3.3 & 3.3 & 3.4 & 3.5 & 3.5 & 3.6 & 3.6 \\
\hline Monthly & 12 & 1.5 & 2 & 2.2 & 2.4 & 2.5 & 2.7 & 2.8 & 2.8 & 2.9 & 3 & 3 & 3.1 & 3.1 \\
\hline Quarterly & 4 & $1^{*}$ & 1.3 & 1.5 & 1.7 & 1.9 & 2 & 2.1 & 2.1 & 2.2 & 2.3 & 2.4 & 2.4 & 2.5 \\
\hline Biannually & 2 & $1 *$ & $1 *$ & 1.1 & 1.3 & 1.4 & 1.5 & 1.6 & 1.7 & 1.8 & 1.9 & 1.9 & 2 & 2 \\
\hline Annually & 1 & $1 *$ & $1^{*}$ & $1^{*}$ & $1 *$ & 1 & 1.1 & 1.2 & 1.3 & 1.4 & 1.4 & 1.5 & 1.5 & 1.6 \\
\hline
\end{tabular}

Table 3. Values for the assessment of the Severity attribute (own elaboration).

\begin{tabular}{|c|c|c|}
\hline Criterion & \begin{tabular}{|c|} 
Categories \\
\end{tabular} & Value \\
\hline \multirow{2}{*}{$\begin{array}{l}\text { Coverage: area of } \\
\text { influence of the EA }\end{array}$} & Widespread: when the effects of the EA go beyond the UA & 2 \\
\hline & Local: when the effects of the EA are located inside the UA & 1 \\
\hline \multirow{2}{*}{$\begin{array}{l}\text { Danger: inherent } \\
\text { qualities of the } \\
\text { substance related to } \\
\text { the EA }\end{array}$} & $\begin{array}{l}\text { Dangerous: corrosive, reactive, explosive, toxic, flammable, } \\
\text { infectious or radioactive substance }\end{array}$ & 5 \\
\hline & Not dangerous: a substance that does not present any kind of hazard & 3 \\
\hline \multirow{5}{*}{$\begin{array}{l}\text { Effects on human } \\
\text { health: level of } \\
\text { damage that the EA or } \\
\text { its associated } \\
\text { substance may cause } \\
\text { on human health }\end{array}$} & Extreme: death or disability & 5 \\
\hline & $\begin{array}{l}\text { Critical: acute or chronic diseases that generate partial or permanent } \\
\text { disability }\end{array}$ & 4 \\
\hline & Severe: diseases that cause temporary disability (e.g. hearing loss) & 3 \\
\hline & $\begin{array}{l}\text { Moderate: temporary diseases that cause any kind of malaise (e.g. } \\
\text { diarrhea) }\end{array}$ & 2 \\
\hline & $\begin{array}{l}\text { Minor: does not have any effect on human health or only generates } \\
\text { minor discomfort or irritation (e.g. headache) }\end{array}$ & 1 \\
\hline
\end{tabular}

\subsection{Significance of the EA}

After assessing the attributes, the significance of each EA has to be determined by using the following formula: Significance $=$ Severity + [Time $x$ Magnitude $]$

\section{Where: Severity $=$ Danger $x$ Effects on human health $x$ Coverage \\ Time $=$ Frequency $x$ Duration

Depending on the result, the significance can be classified according to the values presented in Table 6 .

Table 4. Indicators for the calculation of the magnitude (own elaboration).

\begin{tabular}{|c|c|c|}
\hline EA & Indicator & Formula* \\
\hline $\begin{array}{l}\text { Combustion } \\
\text { emissions }\end{array}$ & $\begin{array}{l}\text { Emission of } \\
\mathrm{CO}_{2} \text {-eq }\end{array}$ & $\begin{array}{l}\qquad E C=\sum_{\alpha, \beta} C C_{\propto} \times F E_{B} \times P C G_{B} \\
E C=\text { Emission of } \mathrm{CO}_{2} \text {-eq }(\mathrm{kg} / \text { month }) \\
C C=\text { Fuel consumption }(\mathrm{TJ} / \text { month }) \\
\mathrm{FE}=\text { Emission factor }(\mathrm{kg} / \mathrm{TJ}) \\
\mathrm{PCG}=\text { Global Warming Potential } \\
\alpha=\text { type of fuel } \\
\beta=\text { Molecule }\end{array}$ \\
\hline $\begin{array}{l}\text { Generation of } \\
\text { recyclable solid } \\
\text { waste }\end{array}$ & $\begin{array}{l}\text { Recyclable solid } \\
\text { waste per capita }\end{array}$ & $\begin{array}{l}\qquad \text { RSRpc }=\frac{\sum R S R}{N} \\
\text { RSRpc }=\text { Recyclable solid waste per capita }(\mathrm{kg} / \mathrm{per}-\mathrm{month}) \\
\mathrm{RSR}=\text { Recyclable solid waste }(\mathrm{kg} / \mathrm{month}) \\
\mathrm{N}=\text { Number of individuals per UA }\end{array}$ \\
\hline $\begin{array}{l}\text { Generation of } \\
\text { chemical waste }\end{array}$ & $\begin{array}{c}\text { Solid chemical } \\
\text { waste per capita }\end{array}$ & $\begin{array}{l}\qquad R Q S p c=\frac{\sum R Q S}{N} \\
\text { RQSpc = Solid chemical waste per capita }(\mathrm{kg} / \text { per-month) } \\
\mathrm{RQS}=\text { Solid chemical waste }(\mathrm{kg} / \text { month }) \\
\mathrm{N}=\text { Number of individuals per UA }\end{array}$ \\
\hline $\begin{array}{l}\text { Consumption of } \\
\text { paper }\end{array}$ & $\begin{array}{l}\text { Consumption } \\
\text { of paper }\end{array}$ & $\begin{array}{l}C P=\sum N R M * 2.26 \\
\mathrm{CP}=\text { Consumption of paper }(\mathrm{kg} / \mathrm{month}) \\
\mathrm{NRM}=\text { Number of realms of paper per month }\end{array}$ \\
\hline
\end{tabular}

\footnotetext{
*Note: the abbreviations of the elements integrating the formulae correspond to the initials of the words in Spanish.
} 
Once the significance is obtained, then some measures need to be designed in order to prevent, correct or mitigate the EA. The priority of these measures can be defined according to the category of the EA and the values presented in Table 6 .

Table 5. Classification categories of some EA (own elaboration). All Unit are in $\mathrm{kg} / \mathrm{month}$.

\begin{tabular}{|c|c|c|c|c|c|c|}
\hline EA & Indicator & $\begin{array}{c}\text { Very } \\
\mathbf{l o w} \\
\mathbf{( 2 )}\end{array}$ & $\begin{array}{c}\text { Low } \\
\mathbf{( 4 )}\end{array}$ & $\begin{array}{c}\text { Medium } \\
\mathbf{( 6 )}\end{array}$ & $\begin{array}{c}\text { High } \\
\mathbf{( 8 )}\end{array}$ & $\begin{array}{c}\text { Very high } \\
\mathbf{( 1 0 )}\end{array}$ \\
\hline $\begin{array}{c}\text { Combustion } \\
\text { emissions }\end{array}$ & $\begin{array}{c}\text { Emission of } \\
\mathrm{CO}_{2-\text { eq }}\end{array}$ & $\leq 10.21$ & $\begin{array}{c}>10.21 \\
\text { and } \leq 102.1\end{array}$ & $\begin{array}{c}>102.1 \\
\text { and } \\
\leq 510.5\end{array}$ & $\begin{array}{c}>510.5 \\
\text { and } \leq 1021\end{array}$ & $>1021$ \\
\hline $\begin{array}{c}\text { Generation of } \\
\text { recyclable } \\
\text { solid waste }\end{array}$ & $\begin{array}{c}\text { Recyclable } \\
\text { solid waste per } \\
\text { capita }\end{array}$ & $\leq 0.23$ & $\begin{array}{c}>0.23 \\
\text { and } \leq 0.26\end{array}$ & $\begin{array}{c}>0.26 \\
\text { and } \leq 0.28\end{array}$ & $\begin{array}{c}>0.28 \\
\text { and } \leq 0.31\end{array}$ & $>0.31$ \\
\hline $\begin{array}{c}\text { Generation of } \\
\text { chemical } \\
\text { waste }\end{array}$ & $\begin{array}{c}\text { Chemical waste } \\
\text { per capita }\end{array}$ & $<0.102$ & $\begin{array}{c}\geq 0.102 \\
\text { and }<0.114\end{array}$ & $\begin{array}{c}\geq 0.114 \\
\text { and } \\
<0.126\end{array}$ & $\begin{array}{c}\geq 0.126 \\
\text { and }<0.138\end{array}$ & $\geq 0.138$ \\
\hline $\begin{array}{c}\text { Consumption } \\
\text { of paper }\end{array}$ & $\begin{array}{c}\text { Consumption } \\
\text { of paper }\end{array}$ & $<2,26$ & $\begin{array}{c}\geq 2,26 \text { and } \\
<4,52\end{array}$ & $\begin{array}{c}\geq 4,52 \text { and } \\
<9,04\end{array}$ & $\begin{array}{c}\geq 9,04 \text { and } \\
<18,08\end{array}$ & $\geq 18,08$ \\
\hline
\end{tabular}

Table 6. Scale of values for the interpretation of the EA's significance (own elaboration).

\begin{tabular}{|c|c|c|c|}
\hline Category & Values & Significance & $\begin{array}{c}\text { Priority for decision- } \\
\text { making and actions }\end{array}$ \\
\hline Critical & $81-100$ & Yes & Immediate \\
\hline Severe & $61-80$ & Yes & Short term \\
\hline Moderate & $41-60$ & Yes & Medium term \\
\hline Minor & $21-40$ & No & Long term \\
\hline Irrelevant & $<20$ & No & Does not require any action \\
\hline
\end{tabular}

\subsection{Assessment of the EA in the MU}

A set of indicators for the MU is proposed in order to complement the analysis. These indicators can be used to assess the environmental management at a larger scale (campus, other land properties of the HEI, or seat) and they can be formulated in absolute terms (e.g. $\mathrm{kg}$ ) or in relative terms (e.g. $\mathrm{kg} /$ per capita or $\mathrm{kg} / \mathrm{month}$ ). The use of absolute indicators allows analysing the performance of the identified EA in a period of time [3]. On the other hand, the use of relative indicators facilitates the comparison of the EA [4] among buildings, other land properties and seats, which allows assessing plans, programs and actions related to the environmental management of the institution. Table 7 presents some of the indicators proposed for the MU of Universidad Nacional de Colombia (Bogotá Seat).

Table 7. Indicators for the UM (own elaboration).

\begin{tabular}{|c|c|c|c|}
\hline Category & EA & $\begin{array}{c}\text { Absolute } \\
\text { indicator }\end{array}$ & $\begin{array}{c}\text { Relative } \\
\text { indicator }\end{array}$ \\
\hline $\begin{array}{c}\text { Atmospheric } \\
\text { emissions }\end{array}$ & $\begin{array}{c}\text { Atmospheric } \\
\text { emissions }\end{array}$ & $\begin{array}{c}\text { Global } \\
\text { emission of } \\
\mathrm{CO}_{2} \text {-eq }\end{array}$ & $\begin{array}{c}\text { Emission of } \mathrm{CO}_{2}- \\
\text { eq } \\
\text { per capita }\end{array}$ \\
\hline \multirow{2}{*}{ Waste } & $\begin{array}{c}\text { Generation of } \\
\text { non-hazardous } \\
\text { waste }\end{array}$ & $\begin{array}{c}\text { Non-hazardous } \\
\text { waste generated }\end{array}$ & $\begin{array}{c}\text { Non-hazardous } \\
\text { waste generated } \\
\text { per capita }\end{array}$ \\
\cline { 2 - 4 } & $\begin{array}{c}\text { Generation of } \\
\text { hazardous waste }\end{array}$ & $\begin{array}{c}\text { Hazardous } \\
\text { waste generated }\end{array}$ & $\begin{array}{c}\text { Hazardous waste } \\
\text { generated per } \\
\text { capita }\end{array}$ \\
\hline
\end{tabular}

\begin{tabular}{|c|c|c|c|}
\hline Category & EA & $\begin{array}{c}\text { Absolute } \\
\text { indicator }\end{array}$ & $\begin{array}{c}\text { Relative } \\
\text { indicator }\end{array}$ \\
\hline \multirow{4}{*}{$\begin{array}{c}\text { Consumption } \\
\text { of resources }\end{array}$} & $\begin{array}{c}\text { Consumption of } \\
\text { water }\end{array}$ & \begin{tabular}{c} 
Consumption of \\
potable water \\
\cline { 2 - 4 }
\end{tabular} & $\begin{array}{c}\text { Consumption of } \\
\text { potable water per } \\
\text { capita }\end{array}$ \\
\cline { 2 - 4 } & $\begin{array}{c}\text { Consumption of } \\
\text { paper }\end{array}$ & $\begin{array}{c}\text { Consumption of } \\
\text { paper }\end{array}$ & $\begin{array}{c}\text { Consumption of } \\
\text { electric poper per capita }\end{array}$ \\
\hline
\end{tabular}

The proposed methodology has two main advantages: first, it allows integrating the environmental analysis with other management systems, such as OHSAS 18001, ISO 900 and ISO 17025, among others; and second, it establishes an indicators system whose frequent assessment allows following up the environmental aspects and evaluate the effectiveness of its management measures. For a detailed description of the methodology please refer to Martínez Bernal et al. (2018) [5] or the working document published in the web page of the Environmental Management Office of Universidad Nacional de Colombia (Bogotá Seat).

\section{Application of the methodology}

Table 8 presents the most important results of the application of the proposed methodology in Universidad Nacional de Colombia (Bogotá Seat). This means, table 8 presents the higher values of EA.

Table 8. Results.

\begin{tabular}{|c|c|}
\hline EA & \% of UA where the EA was significant \\
\hline $\begin{array}{c}\text { Generation of ordinary } \\
\text { solid waste }\end{array}$ & $34,5 \%$ \\
\hline $\begin{array}{c}\text { Consumption of potable } \\
\text { water }\end{array}$ & $28,7 \%$ \\
\hline $\begin{array}{c}\text { Consumption of electric } \\
\text { power }\end{array}$ & $19,5 \%$ \\
\hline $\begin{array}{c}\text { Generation of recyclable } \\
\text { solid waste }\end{array}$ & $13,8 \%$ \\
\hline Discharge of domestic & $10,0 \%$ \\
\hline
\end{tabular}




\begin{tabular}{|c|c|}
\hline EA & \% of UA where the EA was significant \\
\hline wastewater & \\
\hline
\end{tabular}

Source: own elaboration based on the information provided by the Environmental Management Office of Universidad Nacional de Colombia.

\section{Conclusions}

The application of this methodology in the main seat of Universidad Nacional de Colombia determined that the most significant environmental aspects were: generation of ordinary solid waste, consumption of potable water, consumption of electric power, generation of recyclable solid waste, and wastewater discharge. This information led to the formulation of programs aimed at the prevention, mitigation and correction of those aspects and their related environmental impacts.

The methodology proved to be easy to apply and effective for the identification of the main environmental aspects and impacts. It can be used by any other kind of institutions (not only HEIs), because it integrates the community in general and constitutes a didactic tool for environmental education.

\section{References}

1. A. Carretero Peña. Aspectos ambientales: Identificación y Evaluación. AENOR. Madrid. Spain (2007)

2. L. W. Canter. Manual de evaluación de impacto ambiental. Mc Graw Hill (1998)

3. S. Cecchini. Indicadores sociales en América Latina y el Caribe. CEPAL (2005)

4. D.C. Suárez. Conceptos y formulación de indicadores. Programa de información e indicadores de gestión de riesgos de desastres naturales. BID Universidad Nacional de Colombia Sede Manizales. (2003)

5. L. F. Martinez Bernal, A. L. Caro, J. C. Duran Dueñas, N. del P. Pacheco and J. J. Toro. Propuesta metodológica para la identificación y evaluación de aspectos ambientales en instituciones de educación superior. Gestion y Ambiente I. (2018). 